\title{
The study of awareness and adherence in patients receiving anti- hypertensive drugs: a hospital based study
}

\author{
Aalia Tausif, Taruna Sharma*, Sohaib Ahmad, Suman Bala, Juhi Kalra
}

Himalayan Institute of Medical Sciences, Dehradun,

Uttarakhand, India

Received: 04 May 2019

Accepted: 10 June 2019

*Correspondence to:

Dr. Taruna Sharma,

Email: tarunabasera@gmail.com

Copyright: (c) the author(s), publisher and licensee Medip Academy. This is an openaccess article distributed under the terms of the Creative Commons Attribution NonCommercial License, which permits unrestricted noncommercial use, distribution, and reproduction in any medium, provided the original work is properly cited.

\begin{abstract}
Background: Hypertension is an important worldwide public health challenge. It has changed from a trivial cause of death and disability to one of the global burden diseases. The biggest obstacle for inadequate therapeutic control of blood pressure is meagre knowledge, poor attitude, inadequate treatment practices and lack of adherence towards antihypertensive treatment. The present study was planned to assess the awareness of hypertension on various aspects and to evaluate treatment adherence in hypertensive patients.

Methods: This cross-sectional study was conducted on 100 hypertensive patients of both genders visiting medicine OPD at HIMS, Dehradun over a period of six months. A structured and validated questionnaire was used to assess the knowledge, attitude and practice (KAP) among patients. Morisky 8-Item Medication Adherence Questionnaire was used to assess the adherence towards antihypertensive medications. For statistical analysis Chi square test was used.

Results: Out of the 100 patients the median KAP scores were 6(5),5(1) and 10(4) respectively. Most of the subjects had high median scores on attitude but majority of the subjects had low knowledge and self-care practice scores. Further Analysis of data revealed that a poor score in self-care practice was significantly associated to the gender $(\mathrm{p}<0.004)$ as well as to the level of education $(\mathrm{p}<0.006)$. Only $40 \%$ patients were adherent to their medication, this result was statistically associated with the level of education $(\mathrm{p}<0.00001)$.

Conclusions: Hypertensive patients in our community have good attitude but poor knowledge and self-care practices towards management of hypertension. Patients were also found to be non-adherent to their antihypertensive medications.
\end{abstract}

Keywords: Adherence, Awareness, Hypertension

\section{INTRODUCTION}

Hypertension has become a public health challenge. Hypertension itself is not a disease but is known as a disease of complication, more so because of an increased risk of concomitant cardiovascular and renal complications.

During the past century hypertension has changed from a minor cause of death and disability to one of the global burden diseases. It has now been recognised as a foremost risk factor for cardiovascular morbidity and mortality. ${ }^{1}$ As per the recommendations of the $8^{\text {th }}$ joint national committee Hypertension is defined as blood pressure of $150 / 90 \mathrm{mmHg}$ in adults 60 years and older, or 140/90 mm $\mathrm{Hg}$ or higher in adults younger than 60 years. $^{2}$

Nearly a billion people were affected by hypertension in the year 2000 and this proportion is said to rise by $29 \%$ that is 1.56 billion by the next decade. ${ }^{3}$ Hypertension was earlier commonly observed in economically developed countries but was not very prevalent in economically 
developing ones. As there has now been a shift towards sedentary lifestyle of people living in developing countries hypertension has become a major public health problem in India, which is in a midst of an epidemiological transition. Hypertension is known as a silent killer as most people do not have any symptoms at all, but if left uncontrolled may affect many organ systems and lead to end organ damage, resulting in a substandard quality of life, an increased rate of dependency and also increased economic burden on the patient. Over the years, although the rates of detection and control of hypertension have improved, uncontrolled hypertension still remains ubiquitous. ${ }^{4}$ Hypertension is preventable and treatable it can be managed by nonpharmacological as well as pharmacological approaches, but still Blood pressure is inadequately controlled in most hypertensives. The biggest obstacle for inadequate therapeutic control of blood pressure is lack of awareness and knowledge about various aspects of hypertension. ${ }^{5}$ Half of the patients are non-adherent to their treatment. There is no doubt that adherence is in turn influenced by knowledge, attitude and self-care practices (KAP). ${ }^{6} \mathrm{~A}$ proper understanding about these factors will be particularly helpful in assessing adherence towards therapy. The purpose of this study was to generate evidence which will allow scope for the development of interventional strategies that can create community awareness about hypertension, as awareness is the first step in formulating a preventive program for the disease. This may also help Physicians to improve management of hypertension with a better understanding of the barriers that result in non-adherence.

\section{METHODS}

This cross-sectional study was conducted by the department of Pharmacology in collaboration with the department of medicine, HIMS, Dehradun over a period of 6 months after clearance granted by institutional ethics committee. A total of 100 patients attending the medicine OPD more than $18 y$ rs of age of both genders, with and without comorbid conditions were included after taking prior informed consent. Pregnant and lactating women were not included in the study. A simple and validated questionnaire form consisting of 27 questions was used which was divided into 3 parts with questions on knowledge, attitude and practice. The questionnaire was administered to the subjects after being properly explained by the principle investigator and enough time was given to all subjects to understand and answer the questions. Adherence to anti-hypertensive medication was assessed by using The Morisky 8 item medication adherence questionnaire (Table 1).

In addition to this the sociodemographic history was also recorded.Awareness was assessed according to scores given on all 3 parameters. Knowledge and attitude were scored one for right and zero for wrong answers. Patients frequently following self-care practices were given a score of 2, patients who were moderately following these practices were scored 1 and zero was given to patients never following self-care practices. This scoring was given to all questions except 4,7,8 where never was given a score of two, occasional was scored one and frequent was scored zero. The maximum possible score on the knowledge parameter was 13 , on attitude was 5 and in self-care practice was 17 . The minimum score on the 3 parameters was 1,1 and 2. For adherence a score of more than 1 was considered non-adherent and less than 1 was characterised as the patient being adherent to their medication.

\section{Table 1: Morisky 8 item Medication Adherence Questionnaire. $^{7}$}

\begin{tabular}{|ll|}
\hline Questions & $\mathrm{Y} / \mathrm{N}$ \\
\hline $\begin{array}{l}\text { Do you sometimes forget to take your } \\
\text { medicine? }\end{array}$ & $\mathrm{Y}=1 ; \mathrm{N}=0$ \\
\hline $\begin{array}{l}\text { In the past } 2 \text { weeks, were there any days } \\
\text { when you did not take } \\
\text { your medicine? }\end{array}$ & $\mathrm{Y}=1 ; \mathrm{N}=0$ \\
\hline $\begin{array}{l}\text { Have you ever cut back or stopped } \\
\text { taking your medicine without telling } \\
\text { your doctor because you felt worse when } \\
\text { you took it? }\end{array}$ & $\mathrm{Y}=1 ; \mathrm{N}=0$ \\
\hline $\begin{array}{l}\text { When you travel or leave home, do you } \\
\text { sometimes forget to bring along your } \\
\text { medicine? }\end{array}$ & $\mathrm{Y}=1 ; \mathrm{N}=0$ \\
\hline $\begin{array}{l}\text { Did you take all your medicines } \\
\text { yesterday? }\end{array}$ & $\mathrm{Y}=0 ; \mathrm{N}=1$ \\
\hline $\begin{array}{l}\text { When you feel like your symptoms are } \\
\text { under control, do you sometimes stop } \\
\text { taking your medicine? }\end{array}$ & $\mathrm{Y}=1 ; \mathrm{N}=0$ \\
\hline $\begin{array}{l}\text { Do you ever feel hassled about sticking } \\
\text { to your treatment plan? }\end{array}$ & $\mathrm{Y}=1 ; \mathrm{N}=0$ \\
\hline $\begin{array}{l}\text { How often do you have difficulty } \\
\text { remembering to take all your medicine? }\end{array}$ & $\mathrm{Y}=1 ; \mathrm{N}=0$ \\
\hline
\end{tabular}

The statistical analysis was based on standard descriptive statistical tests using the SPSS software (version 20) and presented in form of tables and graphs. Association of demographic characteristics of the patients with awareness and adherence was done using the chi square test and the Mann Whitney $U$ test the $p$ value of $<0.05$ was considered as statistically significant.

\section{RESULTS}

A total of 100 hypertensive patients attending the medicine OPD during the study period were included in the study. There was a male preponderance with $57 \%$ compared to $43 \%$ females. The age ranged from 40-60 years with majority of subjects having hypertension for at least 5 years $(41 \%)$. Forty six percent subjects were illiterate and $68 \%$ people had a history of complications including stroke and renal abnormality seen in maximum patients (46\%) followed by retinopathy (Table 2 ).

Majority of the subjects associated high salt intake (99\%), alcohol (82\%) and being overweight $(75 \%)$ as risk factors for uncontrolled hypertension (Table 3). The median 
(IQR) score on knowledge was 6 (5), attitude 5 (1) and practice $10(4)$ respectively (Table 4$)$.

\section{Table 2: Sociodemographic characteristics of study subjects $(\mathrm{N}=100)$.}

\begin{tabular}{|ll|}
\hline $\begin{array}{l}\text { Sociodemographic } \\
\text { characteristics }\end{array}$ & Subjects $(\mathbf{N}=100)$ \\
\hline Male/Female & $57 / 43$ \\
\hline Mean age(years) & $54.35 \pm 12.55$ \\
\hline $\begin{array}{l}\text { Mean duration of } \\
\text { hypertension (years) }\end{array}$ & $8.97 \pm 7.74$ \\
\hline $\begin{array}{l}\text { Mean Systolic/Diastolic } \\
\text { values (mmHg) }\end{array}$ & $142.76 \pm 8.84 / 81.23 \pm 1.31$ \\
\hline Educational status & \\
\hline illiterate & 46 \\
\hline Senior secondary & 19 \\
\hline Graduate and above & 35 \\
\hline Occupational status & 40 \\
\hline Employed & 32 \\
\hline Housewife & 18 \\
\hline Self employed & 10 \\
\hline Unemployed & $17 / 83$ \\
\hline Alcoholic/Non-Alcoholic & $28 / 72$ \\
\hline Smoker/Non-Smoker & \\
\hline Complications & 23 \\
\hline Stroke & 17 \\
\hline Cardiac disease & 23 \\
\hline Renal abnormality & 5 \\
\hline Retinopathy & \\
\hline
\end{tabular}

Table 3: Knowledge, attitude and practice scores of hypertensive patients $(\mathrm{N}=100)$.

\begin{tabular}{|ll|}
\hline Questions & N $(\%)$ \\
\hline Do you know the normal BP reading is ? & 43 \\
\hline Do you know what high BP is ? & 44 \\
\hline $\begin{array}{l}\text { Do you know what complications can arise } \\
\text { if BP is not controlled? }\end{array}$ & 47 \\
\hline Is high BP hereditable? & 16 \\
\hline $\begin{array}{l}\text { Is excessive salt intake a risk factor for high } \\
\text { BP? }\end{array}$ & 99 \\
\hline $\begin{array}{l}\text { Is excessive alcohol a risk factor for } \\
\text { developing high BP? }\end{array}$ & 82 \\
\hline $\begin{array}{l}\text { Is being overweight a risk factor for high } \\
\text { BP? }\end{array}$ & 75 \\
\hline $\begin{array}{l}\text { Do you know about the symptoms of high } \\
\text { BP? }\end{array}$ & 75 \\
\hline Do you know how high BP is managed? & 7 \\
\hline $\begin{array}{l}\text { Do you know about the symptoms of low } \\
\text { BP? }\end{array}$ & 22 \\
\hline $\begin{array}{l}\text { Do you have to take medications for } \\
\text { hypertension throughout life? }\end{array}$ & 94 \\
\hline $\begin{array}{l}\text { Can antihypertensive medications lower BP } \\
\text { below normal? }\end{array}$ & 33 \\
\hline Is regular BP measurement necessary? & 87 \\
\hline
\end{tabular}

Table 4: Correct response of hypertensive patients towards knowledge $(\mathrm{N}=100)$.

\begin{tabular}{|llll|}
\hline $\begin{array}{l}\text { Variables } \\
\text { (Total score) }\end{array}$ & $\begin{array}{l}\text { Median } \\
\text { score } \\
\text { (IQR) }\end{array}$ & $\begin{array}{l}\text { Minimum } \\
\text { score }\end{array}$ & $\begin{array}{l}\text { Maximum } \\
\text { score }\end{array}$ \\
\hline Knowledge (13) & $6(5)$ & 1 & 13 \\
\hline Attitude (5) & $5(1)$ & 1 & 5 \\
\hline Practice (18) & $10(4)$ & 2 & 17 \\
\hline
\end{tabular}

Table 5: Correct response of hypertensive patient towards attitude $(\mathrm{N}=100)$.

\begin{tabular}{|lc|}
\hline $\begin{array}{l}\text { Questions } \\
\text { Should you reduce salt intake in diet to }\end{array}$ & N $(\%)$ \\
\hline $\begin{array}{l}\text { Do you think regular checking of BP is } \\
\text { important? }\end{array}$ & 36 \\
\hline $\begin{array}{l}\text { Should you keep in touch with physicians } \\
\text { regularly? }\end{array}$ & 74 \\
\hline $\begin{array}{l}\text { Do you think regular medication is } \\
\text { important? }\end{array}$ & 97 \\
\hline $\begin{array}{l}\text { Should you exercise regularly for a healthy } \\
\text { life? }\end{array}$ & 88 \\
\hline
\end{tabular}

Most of the subjects gave correct responses on the attitude scale were it was evident that people realise the need for reducing salt intake in their diet (97\%), regularly checking blood pressure $(86 \%)$ and exercising for a healthy life (97\%) (Table 5).

It was the scores of self-care practice that were in contrast to the other two parameters and showed that the subjects had poor self-care practices which in turn can be a cause of their uncontrolled blood pressure.

Even though having knowledge about high salt intake, increased body weight and lack of physical activity being risk factors for hypertension most of the subjects only occasionally moderated their salt intake $(75 \%)$ and merely $29 \%$ subjects performed physical activity, fewer than that checked their body weight $(4 \%)$. Most of the subjects occasionally missed their medication (46\%) (Table 6).

An association between sociodemographic categories and the KAP scores was also drawn out and it was interestingly noted that the association between gender and practice was statistically significant $(\mathrm{p}<0.05)$. Males had poor practice as compared to the female subjects (Table 7).

The educational status was also found to be associated with all 3 parameters and this association was highly statistically significant $(\mathrm{p}<0.05)$ (Table 8$)$. Out of the total patients only $40 \%$ people had a Morisky score of less than 1 and were hence adherent the remaining were nonadherent to their medication (Table 9).

The association between adherence and gender was significant $(\mathrm{p}<0.05)$ and showed females as being more 
adherent towards their medication as compared to males (Table 10).
Also, the association between the level of education and adherence was highly significant and illustrated mostly the illiterate to be non-adherent to their anti-hypertensive medication (Table 11)

Table 6: Response of hypertensive patients towards self-care practices $(\mathbf{N}=100)$.

\begin{tabular}{|lll|l|}
\hline Questions & Frequent(N\%) & Occasional(N\%) & Never (N\%) \\
\hline How often do you measure your BP? & 13 & 83 & 4 \\
\hline How often do you moderate your salt intake? & 22 & 75 & 3 \\
\hline How often do you avoid fatty food consumption? & 26 & 63 & 11 \\
\hline How often do you consume alcohol? & 79 & 7 & 14 \\
\hline How often do you perform physical exercise? & 29 & 48 & 23 \\
\hline How often do you check your body weight? & 4 & 36 & 60 \\
\hline How often do you smoke? & 75 & 1 & 24 \\
\hline How often do you miss the dose of your medication? & 37 & 46 & 17 \\
\hline How often do you consult your health care provider? & 10 & 87 & 3 \\
\hline
\end{tabular}

Table 7: Association of Gender on awareness among hypertensive patients $(\mathbf{N}=100)$.

\begin{tabular}{|c|c|c|c|c|c|c|c|c|c|c|}
\hline & & \multicolumn{3}{|c|}{ Knowledge (K) } & \multicolumn{3}{|c|}{ Attitude (A) } & \multicolumn{3}{|c|}{ Practice (P) } \\
\hline & & $\begin{array}{l}\text { Median } \\
\text { Score }\end{array}$ & IQR & $P$ value & $\begin{array}{l}\text { Median } \\
\text { Score }\end{array}$ & IQR & $P$ value & $\begin{array}{l}\text { Median } \\
\text { Score }\end{array}$ & IQR & $P$ value \\
\hline \multirow{2}{*}{ Sex } & Female & 8 & 5 & \multirow{2}{*}{0.114} & 5 & 0 & \multirow{2}{*}{0.059} & 12 & 3 & \multirow{2}{*}{$0.004^{\#}$} \\
\hline & Male & 6 & 5 & & 5 & 1 & & 9 & 3 & \\
\hline
\end{tabular}

Mann Whitney U test ${ }^{\#} \mathrm{p}<0.05$

Table 8: Association of Level of Education on awareness among hypertensive patients $(\mathrm{N}=100)$.

\begin{tabular}{|c|c|c|c|c|c|c|c|c|c|c|}
\hline & & \multicolumn{3}{|c|}{ Knowledge } & \multicolumn{3}{|c|}{ Attitude } & \multicolumn{3}{|c|}{ Practice } \\
\hline & & $\begin{array}{l}\text { Media } \\
\text { n score }\end{array}$ & IQR & P value & $\begin{array}{l}\text { Media } \\
\text { n score }\end{array}$ & IQR & P value & $\begin{array}{l}\text { Media } \\
\text { n score }\end{array}$ & IQR & $P$ value \\
\hline \multirow{3}{*}{ Education } & Illiterate & 5 & 2 & \multirow{3}{*}{$0.0001^{\#}$} & 5 & 2 & \multirow{3}{*}{$0.017^{\#}$} & 9 & 3 & \multirow{3}{*}{$0.0006^{\#}$} \\
\hline & $\begin{array}{l}\text { Senior } \\
\text { secondary }\end{array}$ & 8 & 5 & & 5 & 1 & & 10 & 4 & \\
\hline & $\begin{array}{l}\text { Graduate and } \\
\text { above }\end{array}$ & 10 & 2 & & 5 & 0 & & 12 & 3 & \\
\hline
\end{tabular}

Table 9: Morisky 8 item Adherence questionnaire score of hypertensive patients $(\mathrm{N}=100)$.

\begin{tabular}{|lll|}
\hline $\begin{array}{l}\text { Morisky } 8 \text { item medication } \\
\text { adherence questionnaire }\end{array}$ & $\begin{array}{l}\text { Score } \\
\text { (Total } \\
\text { score=8) }\end{array}$ & $\mathbf{N}(\%)$ \\
\hline Adherence & 0 & 40 \\
\hline Non-adherence & $\geq 1$ & 60 \\
\hline
\end{tabular}

Table 10: Association of gender with adherence towards antihypertensive medication $(\mathrm{N}=100)$.

\begin{tabular}{|llll|}
\hline & Males & Females & P value \\
\hline Adherent & 17 & 23 & $*<0.01$ \\
\hline Non-adherent & 40 & 20 & \\
\hline
\end{tabular}

Chi-square test $* \mathrm{p}<0.05$

Table 11: Association of Level of education with adherence towards antihypertensive medication( $(N=100)$.

\begin{tabular}{|c|c|c|c|c|}
\hline & Illiterate & Senior secondary & Graduate and above & $P$ value \\
\hline Adherent & 5 & 8 & 27 & \multirow{2}{*}{$*<0.00001$} \\
\hline Non-adherent & 41 & 11 & 8 & \\
\hline
\end{tabular}




\section{DISCUSSION}

This Knowledge attitude and practice study was aimed to assess the awareness of hypertension among patients as well as their adherence towards anti-hypertensive medication. In the following cross-sectional study, the subjects were of the mean age $54.33 \pm 12.55$ similar mean age were seen in studies conducted by Rahman et al, Bokkampally et al, and Rashidi et al. ${ }^{8-10}$ This showed that hypertension as previously assumed to be a disease of the elderly is not true anymore and its prevalence is seen more in the middle age group. There was a predominance of female subjects over males which was in contract to most studies that showed a male predominance. Most of the subjects in the study were illiterate, in studies conducted by Olivera et al, Ahmad et al in Jaipur and Bokkampally et al, in Telangana, prevalence of hypertension was reported in the illiterate groups or those belonging to low socio-economic backgrounds. ${ }^{11,12,9}$

According to the results obtained in this study most of the subjects had low median scores on knowledge this result was in contrast to that obtained by Sadeq et al, Bokkampally et al, Bhatia et al, Rahman et al, and Shrestha et. al, in which subjects had a good score on the knowledge parameter. ${ }^{13,9,14,8,6}$ Also, in our study there was no association drawn between gender and knowledge which contradicted the study by Sadeq et al, which stated males having better knowledge as compared to females. ${ }^{13}$ The present study shows a significant relationship between level of education and knowledge where most of the graduates had better scores as compared to the illiterate but this was in contrast to a study conducted by Rahman et al, in which no association was found between knowledge scores and level of education. ${ }^{8}$

Majority of the subjects had a positive attitude towards reducing salt intake in diet, regularly checking blood pressure and indulging in physical activity to keep their blood pressure under control. This was in accordance to the results obtained by a large number of studies conducted in India as well as in Nepal, Bangladesh and Iran. ${ }^{6,8,10}$

Even though the subjects had high median scores on attitude, the scores on knowledge were very poor, which was the main cause of poor self-care practices. Poor scores on self-care practice corresponded with most of the studies except a study by Rashidi et al, in which subjects had good practice scores on lowering salt intake in their diet as well as reduced consumption of fatty food. ${ }^{10}$ Practice scores were found to be better in females as compared to men which was a novel finding and contrasted with the study by Rashidi et al, who found no association between gender and self-care practice scores. ${ }^{10}$

In the current study only $40 \%$ subjects showed adherence towards anti-hypertensive medication this might be attributed to the poor self-care practices that the patient had. Even after showing a positive attitude against all risk factors of hypertension only a small number of people applied these in their daily routine. This is because hypertension is mostly asymptomatic and hypertensives fail to recognise its dreadful complications like coronary artery disease, stroke and chronic kidney disease, and often become non-complaint to their medication either due to high costs of daily medication, adverse drug reactions that the subjects are not aware about because of inadequate knowledge imparted to them by the physician, religious and cultural believes or lacking access to medical facilities. Poor adherence showed by the subjects in the study were associated with gender where males were mostly non-adherent as compared to females and the level of education were the illiterate were the most non-adherent group amongst all. The results obtained in this study are completely different from the study by Sadeq et al, in which most of the subjects were adherent to their medication and this result obtained was not associated with gender or the level of education of the patient. ${ }^{13}$

\section{CONCLUSION}

This non-adherence to anti-hypertensive medication has made hypertension as the leading risk factor for morbidity and mortality. The non-complaint attitude of most patients has given hypertension its new name of a silent killer. Therefore, there is a need to improve adherence by either simplifying regimes, imparting knowledge, and modifying patient beliefs. Hence it is the need of the hour to re-in force patient self-management and public health care programmes.

\section{ACKNOWLEDGEMENTS}

Authors would like to thank Himalayan institute of Medical sciences for smooth conduction of the project work. The author is highly obliged and fortunate enough to get constant support and guidance from all the Teaching members of the Department of Pharmacology, who helped in the successful completion of the project work. Above all, Auth would like to thank the clinicians of HIMS who helped me during my project along with the patients who gave their valuable time for me to fill up the questionnaire form. Also, authors would like to thank colleagues for their immense support.

\section{Funding: No funding sources \\ Conflict of interest: None declared \\ Ethical approval: The study was approved by the Institutional Ethics Committee}

\section{REFERENCES}

1. Kearney PM, Whelton M, Reynolds K, Muntner P, Whelton PK, He J. Global burden of hypertension: analysis of worldwide data. Lancet. 2005;365(9455):217-23.

2. Page, Michael R. The JNC 8 hypertension guidelines: an in-depth guide. Am J Managed Care. 2014;20:5-6. 
3. Gupta R, Guptha S. Strategies for initial management of hypertension. Indian J Med Res. 2010;132(5):53142.

4. Ho TM, Estrada D, Agudo J, Arias P, Capillas R, Gibert $\mathrm{E}$ et al. Assessing the impact of educational intervention in patients with hypertension. J Renal Care. 2016;42(4):205-11.

5. Dennis T, Meera NK, Binny K, Sekhar MS, Kishore $\mathrm{G}$, Sasidharan S. Medication adherence and associated barriers in hypertension management in India. CVD Prevention and Control. 2011;6(1):9-13.

6. Shrestha S, Adhikari B, Poudel RS, Thapaliya K, Kharal T, Bastakoti M, et al. Knowledge, Attitude and Practice on Hypertension Among Antihypertensive Medication Users. J Nepal Med Asso. 2016;55(204):86-92.

7. Morisky 8-item medication adherence quessionnaire. Available http://www.uk.stage.cecentral.com/assets/9544/MM AS-8_-_UNTHSC.pdf. Accessed 3 May 2018.

8. Rahman MN, Alam SS, Mia MA. Knowledge, attitude and practice about hypertension among adult people of selected areas of Bangladesh. MOJ Public Health. 2018;7(4):211-4.

9. Bollampally M, Chandershekhar P, Kumar KP, Surakasula A, Srikanth S, Reddy TR. Assessment of patient's knowledge, attitude and practice regarding hypertension. Int J Res Med Sci. 2017;4(8):3299-304.
10. Rashidi Y, Manaflouyan H, Azar FP, Nikniaz Z, Nikniaz L, Ghaffari S. Knowledge, attitude and practice of Iranian hypertensive patients regarding hypertension. J Cardiovasc Thoracic Res. 2018;10(1):14.

11. Oliveria SA, Chen RS, McCarthy BD, Davis CC, Hill MN. Hypertension knowledge, awareness, and attitudes in a hypertensive population. J Gen Internal Med. 2005;20(3):219-25.

12. Ahmad S, Ahmad T. Assessment of knowledge, attitude and practice among hypertensive patients attending a health care facility in North India. Int $\mathrm{J}$ Res Med. 2015;4(2):122-7.

13. Sadeq R, Lafta RK. Knowledge, attitude and practice about hypertension in hypertensive patients attending hospitals in Baghdad, Iraq. South East Asia J Public Health. 2017;7(1):29-34.

14. Bhatia S, Khanka BS, Singh D, Shankar P, Tutu S, Lakhani P, et al. Study of knowledge, attitude and practice of general population of Lucknow towards hypertension. World J Pharm Pharmaceut Sci. 2015;4(10):1674-9.

Cite this article as: Tausif A, Sharma T, Ahmad S, Bala S, Kalra J. The study of awareness and adherence in patients receiving anti-hypertensive drugs: a hospital based study. Int J Basic Clin Pharmacol 2019;8:1634-9. 